\title{
IPTEK BAGI MASYARAKAT (IbM) KELOMPOK USAHA PEMBUAT RUSIP
}

\author{
Robert Napitupulu ${ }^{1)}$, Rodika ${ }^{2)}$ \\ ${ }^{1,2}$ Jurusan Teknik Mesin - Politeknik Manufaktur Negeri Bangka Belitung \\ Kawasan Industri Air Kantung, Sungailiat-Bangka, 33211 \\ Tel: 0717-93586, Fax: 0717-93585, rnapitupulu77@gmail.com
}

\begin{abstract}
Nabila Rusip is one of the IKM built Disperindag Pangkalpinang City which makes the traditional food of the people of Bangka became popular and famous. This success is inseparable from the role of Local Government of Pangkalpinang City which continues to encourage Nabila Rusip business with the provision of appropriate technology in 2015 in processing fish raw materials for the manufacture of rusip. However, at this time the machine can not be operated again due to operator error in using the tool. The purpose of science and technology for the community of the business group of the russians is to repair the fish pressing machine for the manufacture of rusip which was received by the partner from the Industry and Trade Office of Pangkalpinang City. The implementation method starts from inventorying problems, the process of repair and manufacture of machinery, assembly, testing and lastly provides a brief training on how to operate and maintain the correct machine. The results of this activity obtained the fish machine can be re-operated, productivity Nabila Rusip increase and the sale proceeds to increase.
\end{abstract}

Keywords: Rusip, Appropriate Technology, Pres Machine.

\begin{abstract}
Abstrak
Nabila Rusip adalah salah satu dari IKM binaan Disperindag Kota Pangkalpinang yang membuat makanan tradisional orang Bangka menjadi populer dan terkenal. Keberhasilan ini tidak terlepas dari peranan Pemerintah Daerah Kota Pangkalpinang yang terus mendorong usaha Nabila Rusip dengan penyediaan teknologi tepat guna tahun 2015 dalam memproses bahan baku ikan untuk pembuatan rusip. Namun, saat ini mesin tersebut tidak dapat dioperasikan lagi akibat dari kesalahan operator dalam menggunakan alat tersebut. Tujuan dari iptek bagi masyarakat kelompok usaha pembuat rusip adalah untuk memperbaiki mesin pengepres ikan untuk bahan pembuatan rusip yang pernah diterima mitra dari Dinas Perindustrian dan Perdagangan kota Pangkalpinang. Metode pelaksanaan yang dilakukan dimulai dari menginventaris masalah, proses perbaikan dan pembuatan mesin, assembly, ujicoba dan terakhir memberikan pelatihan singkat tentang bagaimana cara pengoperasian dan perawatan mesin yang benar. Hasil dari kegiatan ini diperoleh mesin pengepres ikan dapat beroperasi kembali, produktivitas Nabila Rusip meningkatkan dan hasil penjualan ikut meningkatkan.
\end{abstract}

Kata kunci : Rusip, Teknologi Tepat Guna, Mesin Pres.

\section{PENDAHULUAN}

\subsection{Analisis Situasi}

Rusip atau Rosep adalah makanan tradisional orang Bangka sebagai pengganti saus sambal atau salad, dengan rasa lezat asin cocok dimakan dengan lalapan (id.wikipedia.org). Makanan ini terbuat dari ikan teri/ bilis yang difermentasi, kemudian disimpan dalam botol untuk di awetkan. Rusip diproduksi secara merata didaerah Bangka. Tetapi masih dalam skala rumah tangga (Home industry). Makanan ini sering ditemukan di toko - toko yang menjual makanan khas Bangka, namun ada juga yang dijual langsung dari rumah ke rumah. Proses pembuatan rusip di kepulauan Bangka Belitung khususnya 
masih menggunakan cara - cara tradisional mulai dari membersihkan ikan, meniriskan, mencampur bumbu dan memfermentasi.

\subsection{Kondisi Mitra Saat ini}

Di Kota Pangkalpinang terdapat beberapa industry rumah tangga pembuat rusip, salah satunya adalah Ibu Sunarti (Nabila Rusip) yang beralamat di Jl. Imam Kelurahan Semabung Baru kecamatan Bukit Intan Pangkalpinang. Saat ini usaha pembuatan rusip milik Ibu Sunarti dibantu oleh 3 (tiga) orang tenaga kerja untuk membantu dalam proses produksi. Dalam proses pembuatannya dimulai dari memisahkan ikan, membersihkan ikan, membuang kepala ikan dan mengepres ikan dilakukan dengan cara manual. Setiap hari mereka mengerjakan ikan sebanyak $100 \mathrm{~kg} /$ hari. Ini dilakukan dengan cara manual. Ikan yang datang dipilih dan dipisahkan antara yang besar dan kecil, kemudian dicuci dengan menggunakan air untuk menghilangkan kotoran dan bau pada ikan. Selanjutnya kepala ikan dipisahkan diantara badannya dan kemudian dilakukan proses pengepresan. Proses pengepresan ini dilakukan untuk mengurangi kadar air pada ikan sehingga proses permentasi nantinya baik. Semakin sedikit kandungan air pada ikan, maka rusip yang dihasilkan akan semakin sempurna. Proses pengepresan ikan dilakukan dengan cara meletakkan ikan pada kain serbet, selanjutnya kain serbet diputar dan dipres menggunakan tangan. Hasil yang didapat setiap kali pengepresan sangatlah terbatas hanya menghasilkan 3 ons dan memakan waktu yang lama. Untuk kapasitas ikan 100 kg, bisa diselesaikan dalam waktu 6-8 jam (satu hari penuh).

\subsection{Permasalahan Mitra}

Tahun 2015, Pemerintah Kota Pangkalpinang dalam hal ini Dinas Perindustrian, Perdagangan dan Koperasi menggalakkan Teknologi Tepat Guna (TTG) bagi para IKM (Koran Babel, 2017). Salah satu IKM yang mendapatkan proritas dari pemerintah adalah Ibu Sunarti, yakni sebuah mesin pengepres ikan untuk bahan pembuatan rusip. Ibu Sunarti sangatlah terbantu dengan mesin yang diberikan oleh pemerintah. Mesin tersebut mampu mengepres ikan sebanyak $15 \mathrm{~kg} /$ proses dengan waktu hanya 5 menit. Dengan alat tersebut, ibu sunarti bisa mengurangi tenaga yang dibutuhkan dan waktu yang terbuang. Sisa waktu yang ada bisa digunakan untuk pengerjaan lainnya sebagai ibu rumah tangga. Namun sayang, alat tersebut kini mengalami kerusakan dan tidak dapat berfungsi lagi sehingga ibu sunarti kembali ke manual untuk proses pengepresan ikan sebagai bahan baku pembuatan rusip. Dari survey dan analisa bersama dengan mitra permasalahan yang dihadapi oleh usaha pembuatan rusip milik Ibu Sunarti, yaitu mengenai persoalan produksi yang masih dilakukan secara manual. Adapun persoalannya sebagai berikut:

1. Proses pengepresan ikan masih menggunakan cara manual dengan menggunakan tenaga manusia (Gambar 1). Proses pengepresan ikan dengan berat $100 \mathrm{~kg} /$ hari membutuhkan waktu satu hari penuh dan menguras banyak tenaga. Padahal tenaga kerja yang ada saat ini terbatas. Kemudian, hasil yang dicapai tidaklah sempurna dan tidak merata, hal ini bisa dilihat dari masih banyaknya kandungan air pada ikan. Ini akan berpengaruh pada kwalitas rusip yang dihasilkan atau proses permentasinya kurang bagus.
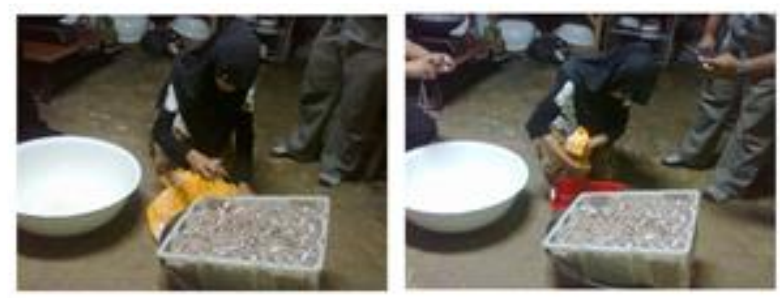

Gambar 1. Proses pengepresan ikan dengan cara manual

2. Mitra pernah mendapatkan bantuan mesin TTG pengepres ikan pada tahun 2015 dan hanya bertahan selama 1(satu) tahun, namun saat ini mengalami kerusakan sehingga tidak bisa lagi digunakan (Gambar 2). 


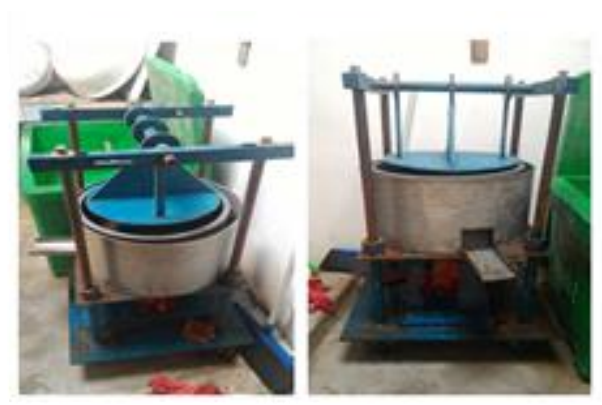

Gambar 2. Mesin Pengpres ikan yang rusak

Adapun permasalahannya terletak pada:

a. Kurang mengertinya mitra dalam pengoperasian mesin sehingga penggunaannya salah atau tidak mengikuti SOP yang diberikan

b. Tidak pahamnya mitra dalam perawatan mesin, sehingga mesin menjadi cepat rusak

\subsection{Makna Eksistensi Mitra di Lingkungan Masyarakat}

Industri kecil dan menengah (IKM) Nabila Rusip banyak memberikan manfaat bagi masyarakat disekelilingnya. Manfaat tersebut diantaranya adalah sebagai berikut.

1) Melestarikan makanan khas Daerah Bangka Belitung

2) Memberi motivasi kepada masyarakat disekitarnya untuk membuka usaha yang sejenis.

3) Menyerap tenaga kerja baru.

Perbaikan mesin pengepres ikan ini diharapkan dapat lebih memberikan kontribusi pada IKM, dan masyarakat setempat termotivasi untuk ikut melestarikan makanan khas Bangka Belitung, selain itu akan membuka lapangan pekerjaan yang baru.

\subsection{Solusi dan Target Luaran Mitra}

Solusi dan Target luaran untuk mitra adalah perbaikan mesin pengepres ikan yang merupakan bantuan dari Dinas Perindustrian, perdagangan dan koperasi tahun 2015, yang meliputi perbaikan system penekan/dongkrak, perbaikan poros yang bengkok, perbaikan system pembuangan air perasan, perbaikan tutup pengepres, dan perbaikan pada system landasan dan roda. Sedangkan solusi dan target luaran yang berkaitan dengan system perawatan mesin adalah memberikan pelatihan singkat kepada mitra bagaimana cara merawat mesin, komponen-komponen apa saja yang akan dirawat dan bagaimana cara perawatannya, system perawatan apa yang digunakan agar mitra jelas dan paham serta bagaiman penggunaan SOP mesin yang baik dan benar.

\section{METODE PELAKSANAAN}

Metode pelaksanaan yang diusulkan untuk menyelesaikan permasalahan diatas adalah memperbaiki mesin pengepres ikan yang rusak sehingga bisa digunakan kembali, serta memberikan pelatihan singkat tentang perawatan mesin. Adapun tahapan-tahapan pelaksanaannya adalah sebagai berikut:

A. Perbaikan Mesin Pengepres Ikan

1. Inventarisasi masalah mesin. Pada tahap ini menginventarisasi permasalahan pada mesin. Inventarisasi dimulai dari:

a. Mengapa mesin tidak berfungsi dengan baik

b. Mengapa dongkrak tidak dapat bekerja

c. Apakah ada komponen peralatan yang mengalami bengkok atau rusak

d. Mengapa system tidak dapat bekerja dengan baik

2. Proses Perbaikan mesin pengepres ikan

Pada tahap ini adalah memperbaiki mesin pengepres ikan yang rusak. Proses perbaikan dilakukan pada bengkel mekanik Politeknik Manufaktur Negeri Bangka Belitung yang meliputi perbaikan system penekan/dongkrak, perbaikan poros yang bengkok, perbaikan system pembuangan air perasan, perbaikan tutup pengepres, dan perbaikan pada system landasan dan roda. 
3. Assembly atau perakitan

Pada tahap ini adalah merakit komponen yang sudah diperbaiki. Proses perakitan dimulai dari pelat landasan, poros pengarah, dudukan pengepres, dudukan saringan, tutup penekan dan dudukan dongkrak. Semua system dirakit jadi satu kesatuan dan mempertimbangkan kesatusumbuan agar system tidak miring.

4. Ujicoba

Pada tahapan ini Melakukan ujicoba mesin dengan dan tanpa bahan baku. Tujuannya adalah untuk melihat apakah system bekerja dengan baik dan dapat Melakukan proses pengepresan dengan baik. Pengujian dengan menggunakan bahan baku ikan bertujuan untuk melihat apakah hasil pengepresan ikan sesuai dengan yang dikehendaki.

\section{B. Pelatihan perawatan mesin}

Perawatan adalah suatu kombinasi dari semua tindakan yang akan dilakukan dalam rangka mempertahankan dan mengembalikan suatu peralatan pada kondisi yang baik (Feriadi, 2012). Pada tahap ini adalah memberikan pelatihan singkat kepada mitra mengenai perawatan mesin yang meliputi bagaimana cara merawat mesin, komponen-komponen apa saja yang akan dirawat dan bagaimana cara perawatannya, system perawatan apa yang digunakan agar mitra jelas dan paham serta bagaiman penggunaan SOP mesin yang baik dan benar. Sumber daya pelatihan yang digunakan ada dosen dari Politeknik Manufaktur Negeri Bangka Belitung yang berkompeten dari program studi perawatan dan perbaikan mesin. Pelatihan ini akan diberikan dalam satu hari, sehingga harapannya mitra memahami dan mengerti prosedur perawatan mesin yang baik dan benar.

Melalui kegiatan ini diharapkan ada partisipasi aktif dari mitra dan tim pengabdi sehingga kegiatan ini diharapkan dapat berjalan dengan baik. Sebagai metoda untuk mengevaluasi kegiatan ini agar tetap berlanjut walaupun kegiatan ini telah selesai adalah dengan tetap menjalin hubungan yang baik antara mitra dan tim pengabdi. Salah satu langkah yang dilakukan tetap memantau dan melihat kondisi mitra, dan memberikan layanan perbaikan apabila ditemukan kendala dilapangan pada saat kegiatan ini sudah selesai. Diharapkan melalui kegiatan ini tetap tercipta hubungan yang baik antara mitra dengan tim pengabdi.

\section{HASIL DAN IPTEKS YANG DITRANSFER KEPADA MITRA}

Proses perbaikan mesin pengepres ikan dilakukan dibengkel mekanik Polmanbabel selama 2 (dua) minggu. Sebelum dilakukan perbaikan dilakukan pengamatan terlebih dahulu mengapa mesin tidak dapat beroperasi dengan baik. Selanjutnya hasil pengamatan dianalisa penyebab terjadinya kerusakan pada mesin pengepres.

Berdasarkan hasil pengamatan dan analisis, diketahui mesin mengalami kerusakan pada 4 (empat) buah poros pengarah yang mengalami bengkok dan system pengepresan yang tidak berfungsi lagi. Hal ini terjadi karena pada saat pengoperasian mesin, posisi tiang pengarah tidak satu sumbu dan kapasitas pengepresan yang melebihi batas kemampuan mesin dan operator tidak memahami akan hal ini. Akibatnya, mesin dipaksa beroperasi dan mengalami bengkok dan rusak. Kemudian selanjutnya dilakukan proses perbaikan.

Proses perbaikan dilakukan dengan cara melakukan pembongkaran ulang dan menggantikan komponen tiang pengarah ( 4 buah) yang mengalami bengkok serta menggantikan system pengepres yang sudah rusak (Gambar 3).
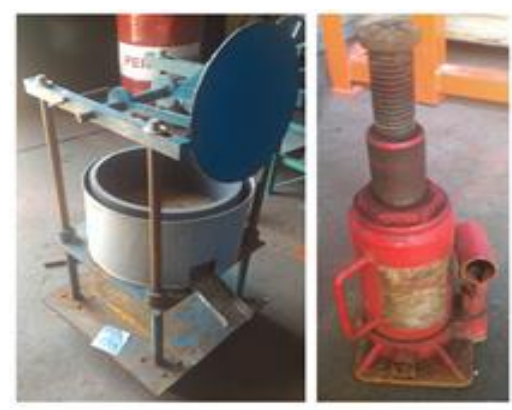

Gambar 3. Proses Perbaikan komponen mesin pengepres yang rusak. 
Selanjutnya komponen-komponen mesin yang rusak diganti dan dibuat baru. Proses pembuatan komponen mesin menggunakan mesin bubut, milling, dan fabrikasi. Setelah komponen selesai dibuat kemudian dilakukan perakitan. Proses perakitan dimulai dengan pemasangan pelat landasan bawah, pemasangan 4 (empat) buah tiang pengarah, pemasangan Pelat dudukan dan wadah, pemasangan tiang pengunci dan terakhir penutup bagian atas. Selanjutnya tahapan akhir dari perbaikan ini adalah proses pengecatan. Gambar 4 berikut merupakan proses perakitan dan pengecatan yang dilakukan dibengkel Polmanbabel.
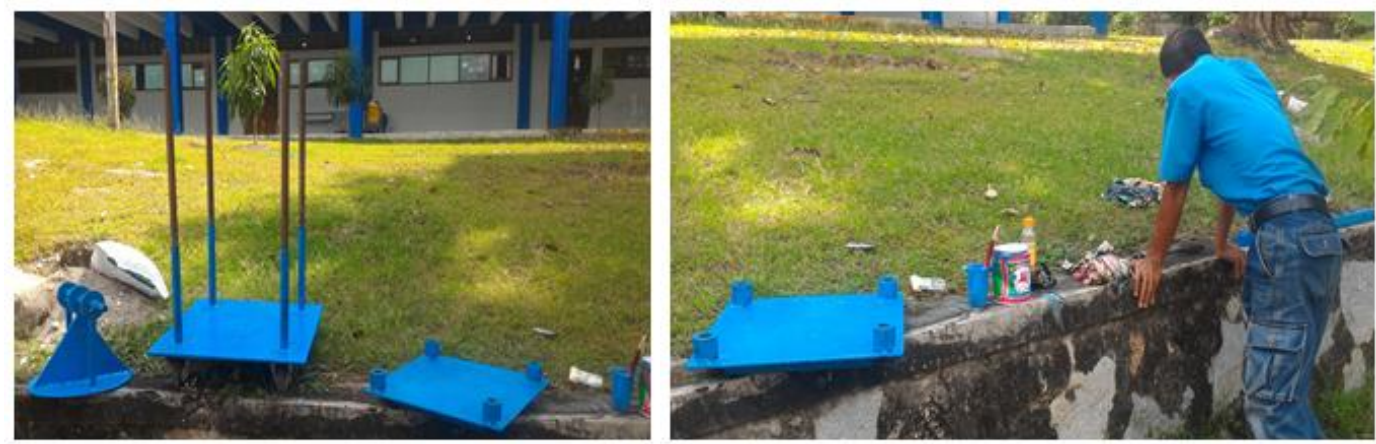

Gambar 4. Proses perakitan dan pengecatan

Secara umum gambaran mesin pengepres ikan untuk bahan baku pembuatan rusip sebelum dan sesudah dilakukan perbaikan ditunjukkan pada Gambar 5.
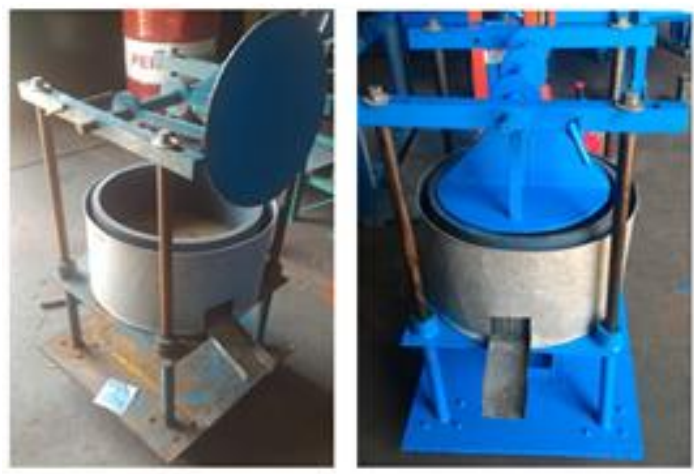

Gambar 5. Mesin sebelum dan sesudah perbaikan

Adapun cara pengoperasian mesin pengepres ikan tersebuat adalah sebagai berikut:

1. Tarik tuas pengunci pada tutup bagian atas

2. Tarik penutup atas menggunakan pengait hingga posisi $90^{\circ}$

3. Pasang tuas pengunci agar penutup atas tidak terjatuh

4. Masukkan bahan baku ikan kedalam karung dan letakkan kedalam wadah pengepres

5. Tarik penutup bagian atas agar sedikit bebas dan Tarik secara perlahan tuas pengunci agar penutup dapat turun secara perlahan

6. Kunci handel pada dongkrak agar dapat dioperasikan

7. Gerakkan tuas pada dongkrak agar dapat naik secara perlahan hingga menekan bahan baku ikan sampai maksimum

8. Tahan dan biarkan mesin menekan bahan baku selama 5 menit, agar kandungan air pada ikan dapat keluar sempurna

9. Kendorkan tuas pengikat pada dongkrak hingga wadah turun sempurna

10. Angkat penutup atas dan masukkan kembali tuas handel penahan agar tidak jatuh

11. Angkat bahan baku ikan dari wadah dan keluarkan dari karung

Proses Ujicoba mesin dilakukan dengan dua tahap, yakni tahap pertama ujicoba tanpa beban.

Ujicoba ini dilakukan untuk memastikan semua part atau bagian berfungsi dengan baik saat 
dioperasikan dan tidak mengalami hambatan. Berdasarkan hasil ujicoba, mesin telah mampu bekerja sesuai dengan fungsinya dan dapat melakukan proses pengepresan dengan baik.

Ujicoba kedua dilakukan dengan memasukkan bahan baku ikan kedalam wadah sebanyak $30 \mathrm{Kg}$. pada tahap ini untuk memastikan bahwa alat dapat bekerja dengan baik. Prosedur pengoperasian mengikuti cara pengoperasian diatas. Berdasarkan hasil ujicoba, mesin mampu mengepres ikan dengan kapasitas $30 \mathrm{Kg} /$ proses dalam waktu 15 menit.

Agar peralatan dapat berumur panjang dan tahan lebih lama, maka dibutuhkan suatu sistem perawatan terhadap suatu peralatan. Perawatan yang cocok dilakukan pada mesin pengepres ikan ini adalah perawatan pencegahan (Preventive). Perawatan ini dilakukan sebelum dan sesudah mesin digunakan. Pelatihan singkat terhadap operator dalam melakukan kegiatan perawatan ini telah dilakukan. Selain itu juga cara pengoperasian mesin sesuai dengan standar pengoperasian prosedur juga diberikan, agar mitra memahami cara mengoperasikan mesin tersebut dengan baik dan benar.

\section{SIMPULAN}

Berdasarkan hasil Pembahasan dapatlah disimpulkan bahwa:

a. Kerusakan yang terjadi pada mesin Mitra disebabkan karena kesalahan operator dalam mengoperasikan mesin

b. Ketidak tahuan operator terhadap kapasitas mesin dapat mengakibatkan kerusakan yang fatal dan membahayakan operator itu sendiri

c. Setelah dilakukan proses perbaikan, mesin pengepres ikan untuk bahan pembuatan rusip dapat beroperasi kembali dan dapat meningkatkan pendapatan mitra.

\section{UCAPAN TERIMA KASIH}

Ucapan terima kasih disampaikan kepada Polmanbabel dan P3KM Polmanbabel yang telah memberikan dana hibah pengabdian masyarakat tahun 2017 dengan baik.

\section{DAFTAR PUSTAKA}

[1]. Ensiklopedia bebas, Masakan kepulauan Bangka Belitung [online], diakses pada tanggal 21 Februari 2017, Available: http:// id.wikipedia.org/.

[2]. Indra Feriadi, Modul Perawatan Mandiri, Politeknik Manufaktur Negeri Bangka Belitung, 2012

[3]. Koran Babel, UMKM Archives - KORAN BABEL [online], diakses pada tanggal 21 februari 2017, Available : http://koranbabel.com/ 